\title{
Effect of a subsidiary pillar on local scour at a bridge pier
}

\author{
S. F. Alshehri ${ }^{1}$, H. Fouli ${ }^{1}$ \& S. Ead $^{2}$ \\ ${ }^{1}$ Civil Engineering Department, King Saud University, Saudi Arabia \\ ${ }^{2}$ Faculty of Engineering, Irrigation and Hydraulics Department, \\ Ain Shams University, Egypt
}

\begin{abstract}
The objective of this experimental study was to examine the effect of a subsidiary pillar, to be located upstream of bridges, on the development of local scour at a single circular bridge pier. Experiments were conducted to investigate the effect of: a) the spacing between the subsidiary pillar and the bridge pier, b) their relative diameters, and c) the Froude number on the dimensions of the scour hole and its temporal development. The experiments were conducted in a rectangular flume under clear water scour conditions mainly at a Froude number of 0.2 (preliminary experiments were also conducted at Froude number of 0.1 and 0.3 ). The results show that the maximum scour depth at the pier could be minimized using three different combinations of spacing and relative diameters. A reduction in the maximum scour depth of approximately $50 \%$ was possible compared to the pier-alone case.

Keywords: local scour, flow altering countermeasures, bridge pier, subsidiary pier, scour hole development.
\end{abstract}

\section{Introduction}

Streambed soil material generally experience erosion due to flowing water in streams. In the context of bridges crossing waterways, the supporting piers help develop excessive local erosion that leads to the formation of scour holes at the piers. Local scour at bridge piers is one of the most serious problems that affect the safety of bridges. Every year, many bridges worldwide fail not because of structural reasons, but due to scouring at their piers and abutments. While there are many studies available in literature that examined scour at piers and proposed 
countermeasures to reduce it, there is still a need for more feasible and practical ideas that can help reduce the development of scour holes at piers.

Scour may be defined simply as the removal of material from the bed and banks of streams by the erosive action of flowing water or tidal currents. The major damage to bridges at stream crossings occurs during floods. Damage is caused for various reasons, the main reason being streambed scour at the bridge foundations, namely piers and abutments, and is typically termed local scour. General scour, on the other hand, occurs irrespective of the existence of the bridge and can occur as either long-term or short-term scour; the two types are distinguished by the time taken for scour development (Melville and Coleman [1]).

Yang [2] reported that the threat of local scour around bridge piers has been known for many years. According to Richardson and Davis [3], local scour around bridge piers is one of the most common causes of bridge failures. It is a widespread problem and has the potential for tragic results. More than 85,000 bridges in the U.S. are vulnerable to scour. Local scour damaged or destroyed 17 bridges in New York and New England during the spring floods of 1987. During the last 30 years, more than 1000 of about 600,000 bridges in the United States have failed, and $60 \%$ of those failures were due to scour. Melville and Coleman [1] stated that in New Zealand, scour damages result in the expenditure of NZ\$36 million per year.

Different countermeasures to reduce local scour at bridge piers are reported in literature. The major countermeasure techniques employed for preventing or minimizing local scour at bridge piers can be classified into two categories: (a) bed armouring, and (b) flow altering. In the former case, the objective is to combat the erosive action of the scour by including mechanisms using hard engineering materials or physical barriers such as rock riprap. In the latter case, the objective is to either inhibit the formation of the scour inducing mechanisms or to cause the scour to be shifted away from the immediate vicinity of the pier (Heidarpour et al. [4]). Bed armouring countermeasures include: riprap stones, reno-mattresses, cabled-tied blocks, gabions, concrete-filled mats or bags, and concrete aprons. Of the many types of armouring countermeasures used for pier protection, a riprap layer consisting of large stones remains the most commonly used armouring countermeasure. Flow altering countermeasures include: sacrificial piles and sills, collars, slots, etc. (Tang et al. [5]).

In the context of bed armouring, Masjedi et al. [6] studied the effect of using circular and square collars fitted to a single circular pier located within a 180degree flume bend. They used collars having different width to pier-diameter ratios placed at different elevations that ranged from the streambed to one pier diameter below the streambed. Their width to pier-diameter ratios ranged between 1.5 and 3.0. They noted that the efficiency of the collar in reducing the scour depth increased with increasing the collar width. They also observed that for both the circular and square collars, the minimum scour depth occurred at the elevation of $0.1 \mathrm{D}$ below the streambed, where $\mathrm{D}$ is the pier diameter. Heidarpour et al. [4] studied the development of scour hole around groups of two and three piers with a collar located at the bed level that was two and three times 
wider than the pier diameter. They concluded that collars were effective for two and three piers in line, and resulted in higher efficiency when the spacing between piers was completely covered with collars. They also concluded that the influence of collars in reducing scour depth at rear piers was more remarkable than the first pier. Zarrati et al. [7] used riprap and combination of collar and riprap to control scour around piers. They concluded that there was no effect of collar diameter on riprap size in their experiments. They have shown that using a collar reduced the stable riprap size $\left(d_{R}\right)$, when $D / d_{R}$ was less than 7.5 (coarse riprap), $D$ being the pier diameter. For $D / d_{R} \geq 7.5$ (fine riprap), the collar had no effect on reducing the stable riprap size. Therefore, collars seemed to be more effective in coarser riprap size by protecting the sides and upstream area of the pier. They concluded that using collars reduced the riprap extent in front and at the sides of piers. They also showed that the eroded riprap volume was $31 \%$ and $57 \%$ less than that for an unprotected pier, when the collar widths were $2 \mathrm{D}$ and $3 \mathrm{D}$, respectively.

In the context of flow altering, Tang et al. [5] used tetrahedral frames protection and reported that it was very effective in reducing the scour depths by $50 \%$ or more. They also showed that the percentage reduction of scour depth decreased as the velocity ratio $V / V_{c}$ decreased, with $V$ being the mean flow velocity and $V_{c}$ the critical flow velocity. In their experiments, $V / V_{c}$ ranged between 0.581 and 1.168. Haque et al. [8] used sacrificial piles to mitigate scour around bridge pier. They examined alternative arrangements of groups of piles placed upstream of a rectangular pier under clear-water scour conditions. They found that when the group of piles was placed at a distance of twice the width of the pier, for which the percentage of blockage of the pier width was $60 \%$, the scour volume was reduced by up to $61 \%$ and the maximum scour depth could be reduced by up to 50\%. Ataie-ashtiani and Beheshti [9] also studied different pile groups' arrangements upstream of a pier; they varied their spacing, the flow rate, and the sediment grain sizes in their experiments. They observed that the scourhole depth for some arrangements of the pile groups increased by two times more than its magnitude for the case of single pile.

In the current study, the results of using a single subsidiary pillar located upstream of a circular bridge pier, as one of the flow altering countermeasures to control the local scour at the pier, are presented. The effects of different relative spacing between the pier and pillar, the diameter ratio and Froude number on the progress of local scour around the pier are examined.

\section{Dimensional analysis}

For the proposed approach of using a subsidiary pillar to minimize local scour at bridge piers, the scour hole geometry at the pier depends on a multitude of variables including: flume width, pier and pillar diameters and inter-spacing, flow conditions (i.e. approach depth and discharge or velocity), sediment properties (mainly specific gravity and grain size), fluid kinematic and dynamic properties (i.e. density and viscosity), type of scour and time. Therefore for the depth of scour $d_{s}$ one can write 


$$
d_{s}=f\left(W, D, D_{S}, S, y, V, g, d_{50}, \rho, \mu, \psi, t_{o}, t\right)
$$

in which $W$ is the flume width, $D$ is the diameter of the pier, $D_{s}$ is the diameter of the subsidiary pillar, $S$ is the clear spacing between the pillar and the pier, $y$ is the approach flow depth, $V$ is the average velocity of flow, $g$ is the gravitational acceleration, $d_{50}$ is the median grain size, $\rho$ is the density of fluid, $\mu$ is the dynamic viscosity of fluid, $\psi$ represents the scour type; i.e. live bed scour or clear water scour, $t_{o}$ is the time corresponding to the asymptotic scour hole depth and $t$ is the time of scour hole depth development. Using dimensional analysis, eqn. 1 can be written in non-dimensional form as:

$$
\frac{d_{S}}{D}=f\left(\frac{W}{D}, \frac{D_{S}}{D}, \frac{S}{D}, \frac{y}{D}, F r, \frac{d_{50}}{D}, R e, \psi, \frac{t}{t_{o}}\right)
$$

in which $F_{r}$ is the approach flow Froude number $\left(F_{r}=V / \sqrt{ }(g y)\right)$, and $R_{e}$ is its Reynolds' number $\left(R_{e}=\rho V R / \mu\right.$; $R$ being the hydraulic radius of the flume's cross section). After simplification of eqn. 2 and eliminating the variables that are not significantly relevant; i.e. $R_{e}$ and those with constant values in this study; i.e. $W$, $d_{50}$, and $y$, one can obtain:

$$
\frac{d_{s}}{D}=f\left(\frac{D_{S}}{D}, \frac{s}{D}, F r, \psi, \frac{t}{t_{o}}\right)
$$

The dependence of $d_{s}$ on each of the parameters in eqn. 3 has been studied.

\section{Experimental setup and procedures}

\subsection{Experimental setup}

The experiments were conducted in a rectangular flume having an overall length of $10.55 \mathrm{~m}$. This length comprises the inlet; the outlet and the working section (see fig. 1). The flume is $0.50 \mathrm{~m}$ deep, $0.30 \mathrm{~m}$ wide and is constructed on an adjustable steel frame, with its bed approximately $1.60 \mathrm{~m}$ above the floor. The flume is equipped with two controlling gates: one vertical sluice gate at the upstream end and a tailgate at the downstream end of the flume. The tailgate was adjusted to maintain a constant flow depth $(y)$ of $0.20 \mathrm{~m}$ in all experiments. Water is delivered to the flume by a pump having a capacity range of 70-180 $\mathrm{m}^{3} / \mathrm{hr}$. The discharge is measured by a V-notch installed at the downstream end in the outlet section. A point-gauge mounted on a sliding aluminum frame was used to measure surface elevations. An energy dissipating plate located at the flume inlet was used to reduce the flow turbulence. This, in addition to the length of the flume downstream of the inlet section and upstream of the testing section, resulted in having fully developed flow at the subsidiary pillar and the pier. A constant pier diameter of $0.03 \mathrm{~m}$ was chosen throughout the experiments, making $D / W=0.1$. The diameters of the subsidiary pillars were chosen such that they are smaller, equal and larger than the pier diameters; $D_{s} / D$ was $4 / 3,3 / 3,2 / 3$. In addition, six values for the spacing between the pier and the pillar were used; $S=$ $0,0.5 \mathrm{D}, \mathrm{D}, 1.5 \mathrm{D}, 2 \mathrm{D}$ and $3 \mathrm{D}$. 

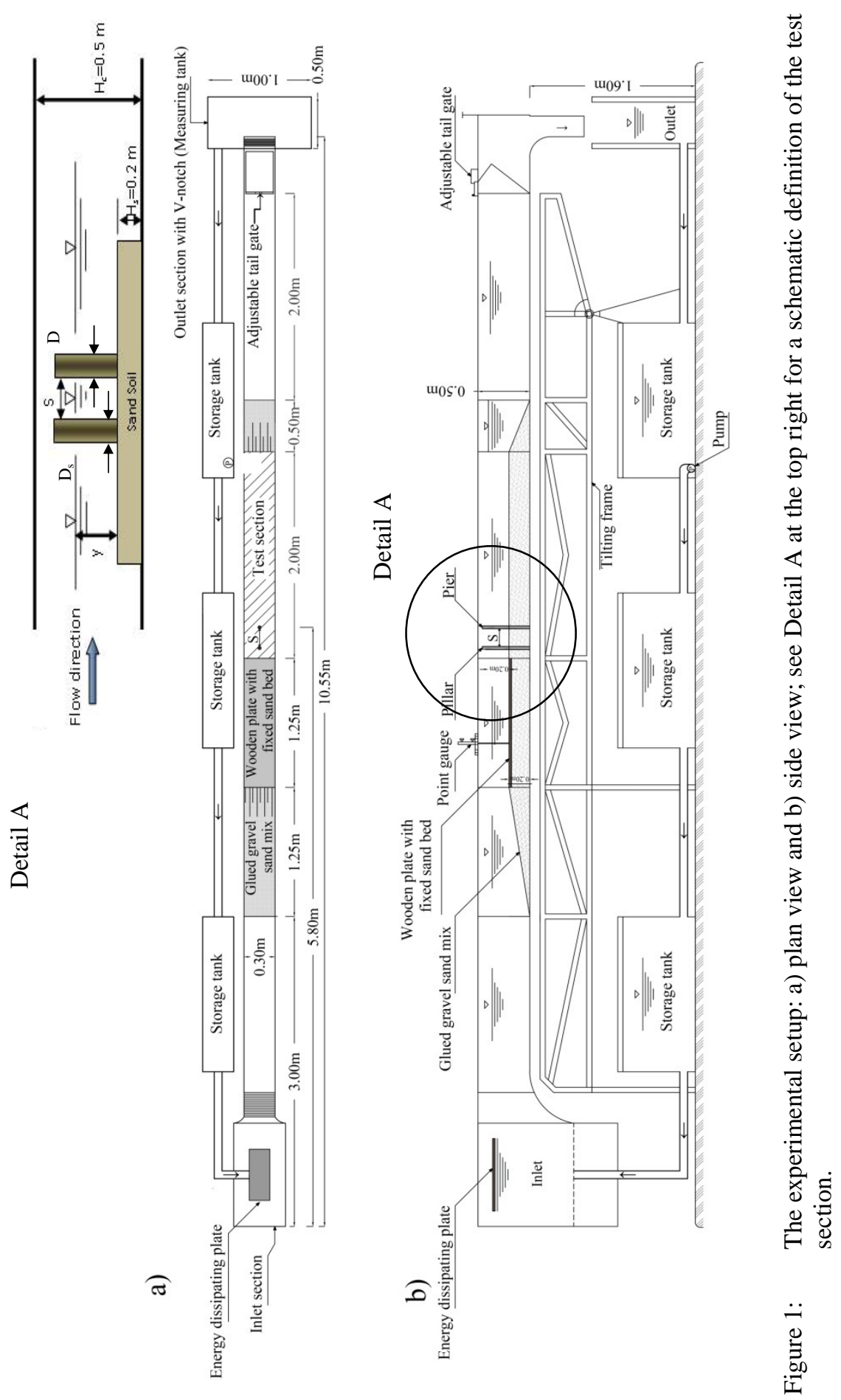
A layer of sand approximately $0.20 \mathrm{~m}$ thick was placed in the working section. The sand had a median diameter $\left(d_{50}\right)$ of approximately $0.9 \mathrm{~mm}$. Raudkivi [10] reported that scour depth increases as sediment becomes less uniform. Sediment uniformity is defined as:

$$
\sigma_{g}=\sqrt{\frac{d 84}{d 16}}
$$

From the sediment gradation curve of the used sand, the value of $d_{84}$ is $1.04 \mathrm{~mm}$, and the value of $d_{16}$ is $0.59 \mathrm{~mm}$; a uniformity factor $\left(\sigma_{g}\right)$ was found to be 1.33 . Raudkivi [10] suggests the criterion for having uniform soil material is $\sigma_{g}<1.35$. Therefore, the sand used in this study can be considered uniform, and hence sediment non-uniformity will not affect the scour depth.

\subsection{Description of experiments}

Twenty two experiments were conducted under different flow conditions as listed in table 1 . The experiments were conducted on two stages: a) stage 1, which included experiments 1 to 4 with a single pier only, and b) stage 2, which included experiments 5 to 22 with the pier and the subsidiary pillar. During stage 1 , experiments 1 and 2 were conducted to compare between live bed and clear water scour, in addition to estimating the time of equilibrium scour $\left(t_{o}\right)$. Experiments 2, 3 and 4 were conducted to investigate the effect of Froude number on the scour hole dimensions and to observe the temporal development of the scour hole under clear water scour conditions. Experiments 1 to 4 were started by allowing water to flow over the horizontal bed for different times (5, 15, 30, 60, 240, 360 and 720 minutes), to estimate the time to reach the equilibrium scour depth. In experiment 1 , the pier was located at $6.20 \mathrm{~m}$ from the start of the inlet channel and live bed scour occurred. In experiment 2, the pier was moved gradually further upstream until no live bed scour was observed. The new location for clear water scour in experiments 2 to 22 was $5.80 \mathrm{~m}$ from the start of the inlet channel. As an additional precaution to avoid live bed scour, a wooden plate with fixed sand bed and glued gravel-sand mix was installed upstream of the test section as shown in fig. 1. Also, a wooden plate with fixed sand bed connected between the sloping frame and the test section (see fig. 1).

During stage 2, experiments 5 to 22 were performed to examine the effect of the subsidiary pillar on local scour at the pier; they were repeated at increasing clear distance between the pier and the subsidiary pillar and with different diameters of the subsidiary pillar. The preliminary results from experiments 1 to 4 were used as a guide in performing experiments 5 to 22. This refers to the time of equilibrium $\left(t_{o}\right)$, the location of the pier for clear water scour to occur and the appropriate Froude number. Table 1 lists summary of the experiments and their conditions, as well as the main results discussed in the following section. Experiments 2, 3 and 4 were repeated few times to ensure repeatability; based on the scour depth measurements the error in measuring $d_{s}$ was estimated to be within $\pm 3 \mathrm{~mm}$. 
Table 1: $\quad$ List of the experiments and their main results.

\begin{tabular}{|c|c|c|c|c|c|c|c|c|}
\hline $\begin{array}{c}\text { Exp. } \\
\text { no. }\end{array}$ & $\begin{array}{c}\mathrm{D} \\
(\mathrm{m})\end{array}$ & $\begin{array}{c}\mathrm{D}_{\mathrm{s}} \\
(\mathrm{m})\end{array}$ & $\begin{array}{c}\mathrm{S} \\
(\mathrm{m})\end{array}$ & $\mathrm{F}_{\mathrm{r}}$ & $\begin{array}{c}\mathrm{d}_{\mathrm{sm}} \\
(\mathrm{m})\end{array}$ & $\mathrm{D}_{\mathrm{s}} / \mathrm{D}$ & $\mathrm{S} / \mathrm{D}$ & $\mathrm{d}_{\mathrm{sm}} / \mathrm{D}$ \\
\hline $1^{*}$ & 0.03 & - & - & 0.1 & 0.029 & - & - & 0.967 \\
\hline 2 & 0.03 & - & - & 0.1 & 0.033 & - & - & 1.100 \\
\hline 3 & 0.03 & - & - & 0.2 & 0.046 & - & - & 1.533 \\
\hline 4 & 0.03 & - & - & 0.3 & 0.084 & - & - & 2.800 \\
\hline 5 & 0.03 & 0.02 & 0 & 0.2 & 0.040 & 0.667 & 0.00 & 1.333 \\
\hline 6 & 0.03 & 0.02 & $0.5 \mathrm{D}$ & 0.2 & 0.022 & 0.667 & 0.50 & 0.733 \\
\hline 7 & 0.03 & 0.02 & $\mathrm{D}$ & 0.2 & 0.035 & 0.667 & 1.00 & 1.167 \\
\hline 8 & 0.03 & 0.02 & $1.5 \mathrm{D}$ & 0.2 & 0.025 & 0.667 & 1.50 & 0.833 \\
\hline 9 & 0.03 & 0.02 & $2 \mathrm{D}$ & 0.2 & 0.040 & 0.667 & 2.00 & 1.333 \\
\hline 10 & 0.03 & 0.02 & 3D & 0.2 & 0.034 & 0.667 & 3.00 & 1.133 \\
\hline 11 & 0.03 & 0.03 & 0 & 0.2 & 0.036 & 1.000 & 0.00 & 1.200 \\
\hline 12 & 0.03 & 0.03 & $0.5 \mathrm{D}$ & 0.2 & 0.040 & 1.000 & 0.50 & 1.333 \\
\hline 13 & 0.03 & 0.03 & $\mathrm{D}$ & 0.2 & 0.035 & 1.000 & 1.00 & 1.167 \\
\hline 14 & 0.03 & 0.03 & $1.5 \mathrm{D}$ & 0.2 & 0.020 & 1.000 & 1.50 & 0.667 \\
\hline 15 & 0.03 & 0.03 & $2 \mathrm{D}$ & 0.2 & 0.025 & 1.000 & 2.00 & 0.833 \\
\hline 16 & 0.03 & 0.03 & 3D & 0.2 & 0.035 & 1.000 & 3.00 & 1.167 \\
\hline 17 & 0.03 & 0.04 & 0 & 0.2 & 0.053 & 1.333 & 0.00 & 1.767 \\
\hline 18 & 0.03 & 0.04 & $0.5 \mathrm{D}$ & 0.2 & 0.021 & 1.333 & 0.50 & 0.700 \\
\hline 19 & 0.03 & 0.04 & $\mathrm{D}$ & 0.2 & 0.025 & 1.333 & 1.00 & 0.833 \\
\hline 20 & 0.03 & 0.04 & $1.5 \mathrm{D}$ & 0.2 & 0.024 & 1.333 & 1.50 & 0.800 \\
\hline 21 & 0.03 & 0.04 & $2 \mathrm{D}$ & 0.2 & 0.026 & 1.333 & 2.00 & 0.867 \\
\hline 22 & 0.03 & 0.04 & 3D & 0.2 & 0.025 & 1.333 & 3.00 & 0.833 \\
\hline
\end{tabular}

*Live bed scour is only represented by experiment 1 ; the other experiments are classified as clear water scour.

\section{Results and discussion}

Fig. 2 shows the change in scour depth with time in experiment 1 (live bed scour) and experiment 2 (clear water scour) at $F_{r}=0.1$. It can be seen that in experiment 1 , the scour depth fluctuated with time. One can distinguish between three zones:

i) Zone 1, where there is an initial rapid development of the scour depth $d_{s}$ $\left(d_{s}\right.$ increased from zero to $33 \mathrm{~mm}$ in 30 minutes, i.e. at a rate of 66 $\mathrm{mm} / \mathrm{hr}$ ).

ii) Zone 2, where there is a cyclic fluctuating behavior of $d_{s}$ whose amplitude decays gradually with time. An initial deposition is observed at an estimated rate of $15.4 \mathrm{~mm} / \mathrm{hr}$. This deposition is followed by erosion at an estimated rate of $2.5 \mathrm{~mm} / \mathrm{hr}$ until $t$ of $240 \mathrm{~min}$. Afterwards, a second cycle of deposition is observed at an estimated rate of $2.3 \mathrm{~mm} / \mathrm{hr}$. 
iii) Zone 3, where there is minimal change in $d_{s}$ resulting in very slow erosion rate of $0.5 \mathrm{~mm} / \mathrm{hr}$. The cyclic erosion-deposition-erosion behavior would have continued, but at much slower rates had the experiment lasted for longer times than $720 \mathrm{~min}$.

In experiment 2 (clear water scour), the scour depth development showed a continuously increasing depth with time; i.e. erosion only. An initial linear rapid increase in $d_{s}$ of $32 \mathrm{~mm}$ occurred in 5 minutes (at a rate of $372 \mathrm{~mm} / \mathrm{hr}$ ). This high rate is followed by a very low rate of erosion estimated at $0.34 \mathrm{~mm} / \mathrm{hr}$ until the end of the experiment. A change in $d_{s}$ of only $2 \mathrm{~mm}$ occurred in 6 hours, between 360 minutes and 720 minutes. Based on the results of experiments 1 and 2, 94\% of $d_{s}$ occurred during 360 minutes. Due to time constraints in the lab facility, the time to equilibrium $\left(t_{o}\right)$ was considered to be 360 minutes and the maximum scour depth $\left(d_{s m}\right)$ in the following experiments was measured at that time. It is important to note that the maximum scour depth presented in Table 1 corresponds to $t_{o}=360 \mathrm{~min}$.

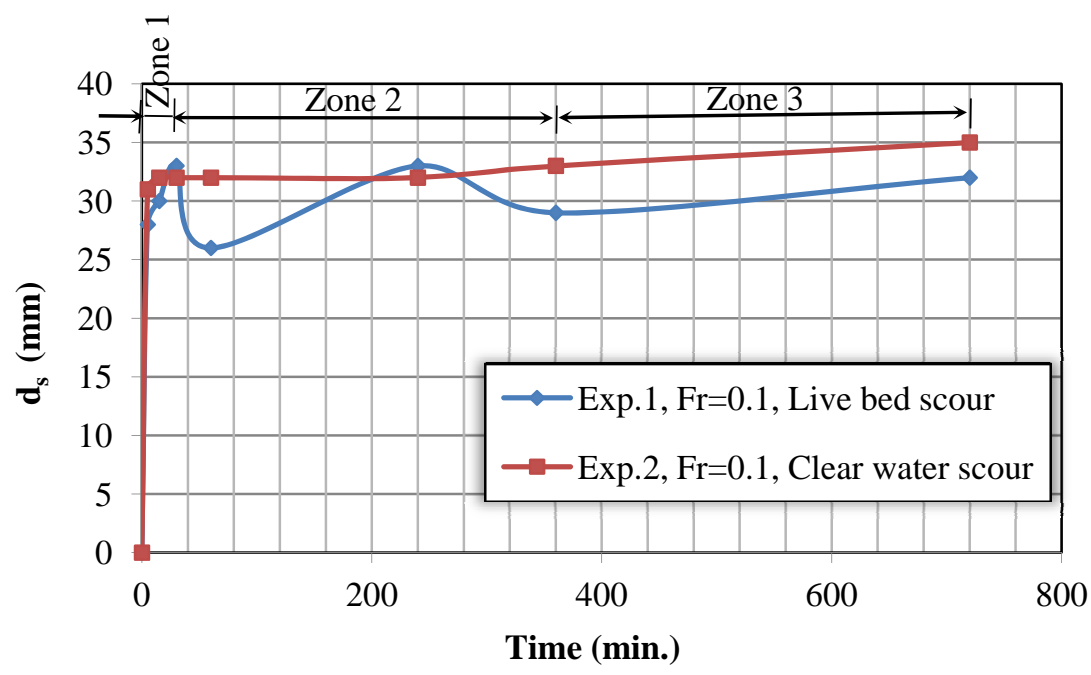

Figure 2: $\quad$ The temporal development of the scour hole depth in Exps.1 and 2.

Fig. 3 shows the temporal development of the scour depth in experiments 2, 3 and 4 with Froude numbers of 0.1, 0.2 and 0.3 , respectively. In fig. 3, the time was normalised by the time to equilibrium scour $\left(t_{o}\right)$ and the scour depth was normalised by the pier diameter $(D)$. From fig. 3, the development pattern of the scour hole depth $\left(d_{s}\right)$ seems similar for the different Froude numbers. However, it appears that the time of initial rapid development of $d_{s}$ (zone 1) is longer for $F_{r}=$ 0.3 than for $F_{r}=0.1$ and 0.2 . It is also noticeable that for $F_{r}=0.1$ and 0.2 , this time of initial development is almost the same. For $F_{r}=0.1$ and $0.2, d_{s} / D$ was 1.1 at $t / t_{o}$ of 0.01 , while for $F_{r}=0.3, d_{s} / D$ was 2.2 at $t / t_{o}$ of 0.04 . In zone 2 , however, the value of $d_{s} / D$ increased non-linearly with increasing Froude number at any 


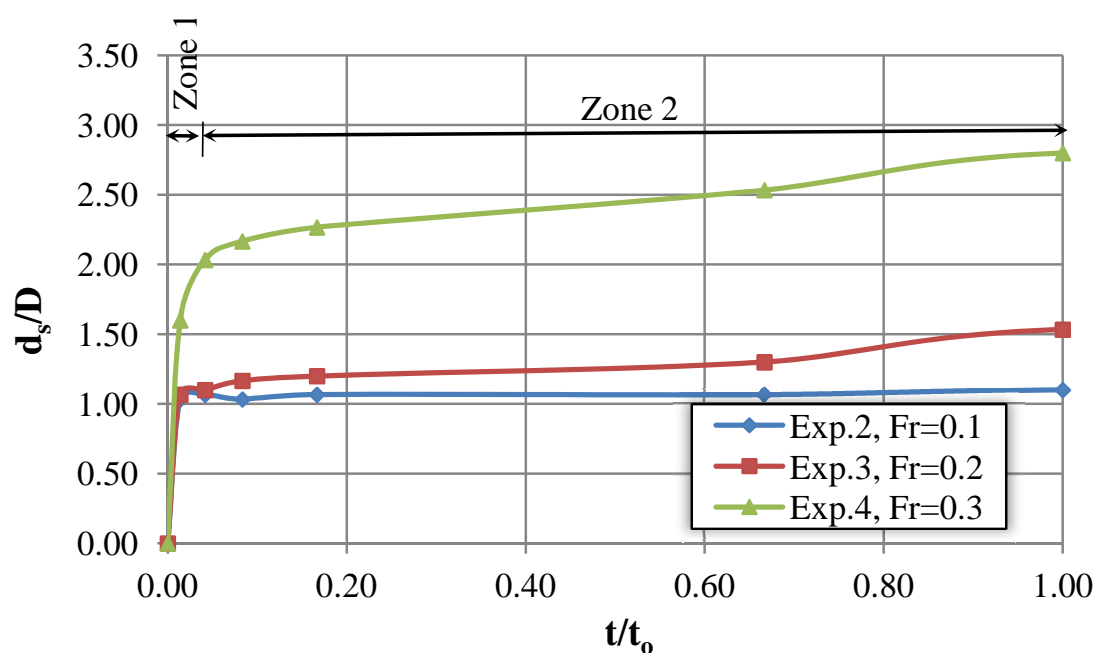

Figure 3: The temporal development of the scour hole depth at different $F_{r}$.

given time. At equilibrium $\left(t / t_{o}=1.0\right)$, the value of $d_{s} / D$ increased from 1.1 to 1.53 for an increase of Froude number from 0.1 to 0.2 . However, when the Froude number increased from 0.2 to $0.3, d_{s} / D$ increased to 2.8 .

The spatial pattern of the scour hole was also examined at different Froude numbers at the equilibrium time $\left(t_{o}\right)$. Fig. 4(a) and 4(b) show the dimensions and shape of the scour hole across the channel and in the stream direction, respectively for different Froude numbers. From fig. 4 (a), it is obvious that there is a quasi-linear rate of decrease of $d_{s}$ with $Y$ that is almost the same for $F_{r}=0.1$ and 0.2 and is estimated at a slope of $0.5 \mathrm{~mm} / \mathrm{mm}$. However, for $F_{r}=0.3$ the rate of decrease of $d_{s}$ with $Y$ changed from approximately $0.47 \mathrm{~mm} / \mathrm{mm}$ up to $Y= \pm 5 \mathrm{~cm}$, then it decreased significantly to $0.07 \mathrm{~mm} / \mathrm{mm}$ from $Y= \pm 5 \mathrm{~cm}$ up to $Y= \pm 8 \mathrm{~cm}$. While the measurements in fig. 4(a) were taken only up to $Y= \pm 8 \mathrm{~cm}$, the profiles were observed visually to maintain the slopes away from the pier and up to the flumes sides.

Fig. 4(b) shows the profiles of the scour hole in the flow direction. It can be seen that the scour hole extended upstream of the pier up to the wooden plate for $F_{r}=0.3$. In addition, underneath erosion occurred below the wooden plate; therefore it was decided to use $F_{r}$ of 0.2 in experiments 5 to 22, as it provided larger scour depths than $F_{r}=0.1$, yet the scour hole profiles were still within the flume's boundaries and did not extend to the sides or the wooden plate upstream. In fig. 4(b), one can distinguish between four zones where the bed slope is different. Zones $\mathrm{A}$ and $\mathrm{D}$ have milder slopes than zones $\mathrm{B}$ and $\mathrm{C}$. From the measurements, the bed slopes for zones $A$ and $D$ were about $0.09 \mathrm{~mm} / \mathrm{mm}$ and $0.12 \mathrm{~mm} / \mathrm{mm}$, respectively. While for zones B and C, the slopes were about 0.5 $\mathrm{mm} / \mathrm{mm}$ and $0.3 \mathrm{~mm} / \mathrm{mm}$, respectively. 


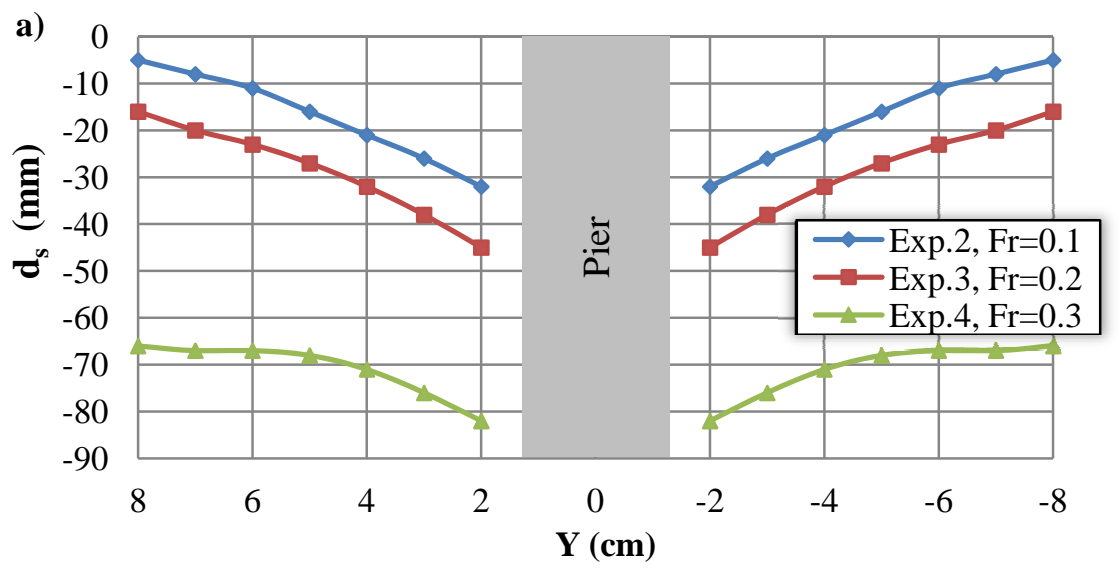

b)

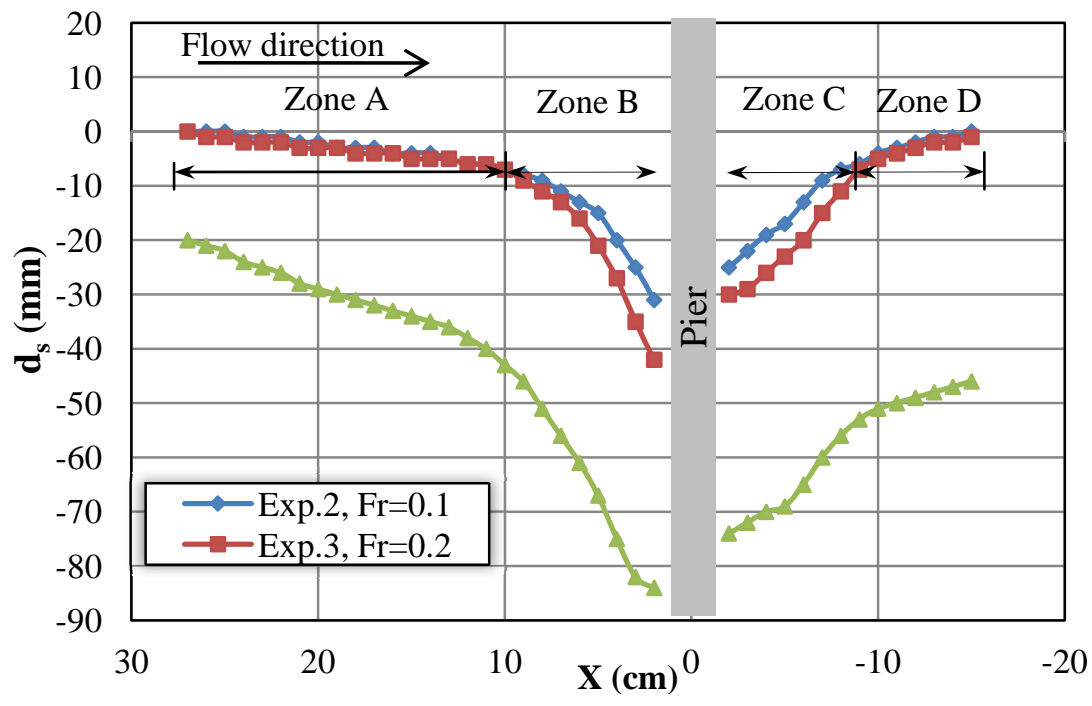

Figure 4: The scour hole dimensions and profiles at equilibrium for different Froude numbers: a) across the channel and b) stream wise.

Fig. 5 illustrates the maximum scour depth normalized by the pier diameter $\left(d_{s m} / D\right)$ against the relative spacing $S / D$ for different relative diameters $D_{s} / D$. The results of experiments 5 to 10 with $D_{s} / D=0.67$ show that the maximum scour depth decreases then increases in a cyclic pattern with increasing $S / D$, with a minimum value at $S / D=0.5$. The results of experiments 11 to 16 with $D_{s} / D=$ 1.00 show that the maximum scour depth increases then decreases, and then increases again with increasing $S / D$; the minimum value occurred at $S / D=1.5$. The results of experiments 17 to 22 with $D_{s} / D=1.33$ show that the maximum scour depth decreases then slightly increases and stagnates with increasing $S / D$. 
Therefore, for experiments 5 to 10 and 17 to 22 with $D_{s} / D=0.67$ and 1.33 , the minimum value of $d_{s m}$ was reached at $S / D=0.5$, while in experiments 11 to 16 with $D_{s} / D=1.00$, the minimum value of $d_{s m}$ was reached at $S / D=1.5$.

Fig. 5 also shows that the data obtained from the previous study done by Ataie-Ashtani and Beheshti [9]. They conducted their experiments at $F_{r}=0.4$ and used soil that had $d_{50}=0.98 \mathrm{~mm}$. They reported that the maximum scour depth decreased and then slightly increased with increasing $S / D$, and reached the minimum value at $S / D=1.0$. Chiew and $\operatorname{Lim}[11]$ did another study with $\mathrm{F}_{\mathrm{r}}=0.5$ and $d_{50}=0.96 \mathrm{~mm}$ and concluded that the maximum scour depth decreased and then stabilized with increasing $S / D$, and reached the minimum value at $S / D=4.3$.

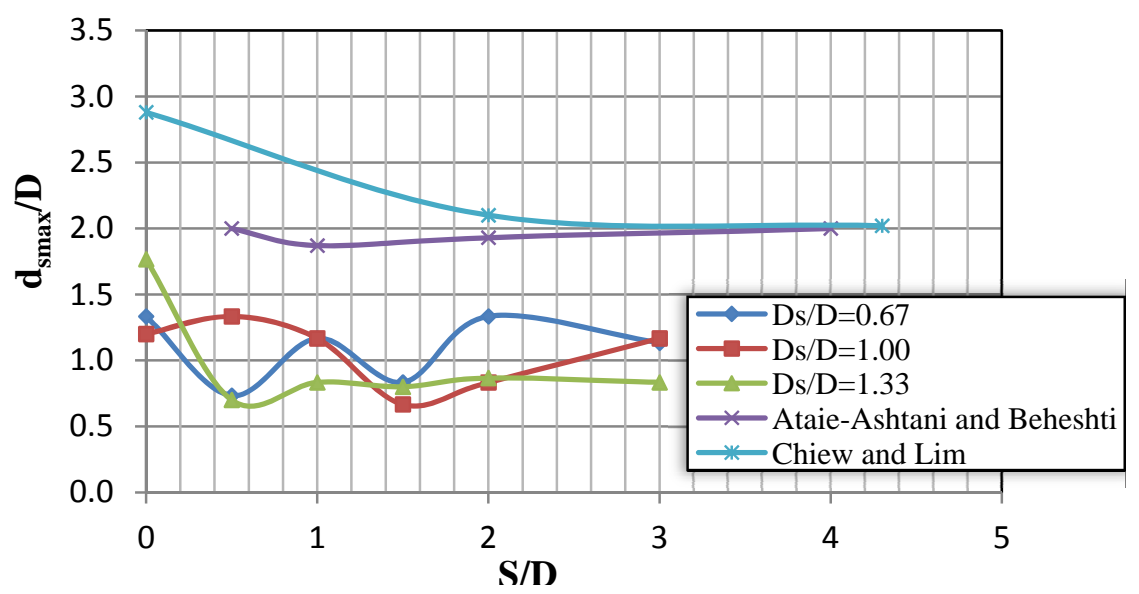

Figure 5: $\quad d_{s m} / D$ against the $S / D$ for different $D_{S} / D$ values.

\section{Conclusions}

In this paper reduction of scour around a circular bridge pier using a subsidiary pillar has been examined experimentally under clear water scour conditions using uniform sandy soil. The experiments were performed mainly at $F_{r}$ of 0.2 .

Results of this study supplement those of previous studies performed at $F_{r}=0.4$ and 0.5 , with almost the same $d_{50}$-sand soil. Based on the results of the present study, it is recommended, for having minimum local scour depths at the pier, to use either a pillar with the same diameter as that of the pier at a clear spacing of 1.5 times the diameter, or to use smaller or larger diameter pillars ( $D_{s}=0.67$ or 1.33 times the pier diameter) located at a spacing of 0.5 the pier diameter.

\section{References}

[1] Melville B. W. and Coleman S. E. (2000), “Bridge scour”, Water Resources Publications, LLC. 
[2] Yang Q. (2005), “Numerical Investigations of Scale Effects on Local Scour around a Bridge Pier", Master thesis at the Department of Civil Engineering in the Florida State University.

[3] Richardson, E. V. and Davis, S. R. (2001), "Evaluating Scour at Bridges", $4^{\text {th }}$ Ed, Hydraulic Engineering Circular No 18, Rep. No. FHWA NHI 01001. U.S. Dep. of Transportation, Federal Highway Administration, Washington, D.C.

[4] Heidarpour M., Afzalimehr H., and Izadinia E. (2010), "Reduction of local scour around bridge pier groups using collars”, International Journal of Sediment Research.

[5] Tang H. W., Ding B., Chiew Y.M., and Fang S. L. (2009), "Protection of bridge piers against scouring with tetrahedral frames", International Journal of Sediment Research.

[6] Masjedi A., Bejestan M. S., and Esfandi A. (2010), "Experimental study on local scour around single oblong pier fitted with a collar in a 180 degree flume bend", International Journal of Sediment Research.

[7] Zarrati A. R., Chamani M. R., Shafaie A., and Latifi M. (2010), "Scour countermeasures for cylindrical piers using riprap and combination of collar and riprap", International Journal of Sediment research.

[8] Haque M. A., Rahman M. M., Islam G. T., and Hussain M. A. (2007), "Scour mitigation at bridge piers using sacrificial piles", International Journal of Sediment Research.

[9] Ataie-ashtiani B. and Beheshti A. A. (2006), "Experimental Investigation of Clear-Water Local Scour at Pile Groups", Sharif University of Technology, Tehran, Iran.

[10] Raudkivi, A. J. (1991), "Loose Boundary Hydraulics”, $3^{\text {rd }}$ Ed. Pergamon Press, Oxford.

[11] Chiew Y. and Lim S., (2002), "Protection of bridge piers using a sacrificial sill”, Nanyang Technology University, Singapore. 